\section{Formation of Pyromorphite in Anglesite-Hydroxyapatite Suspensions under Varying pH Conditions}

\author{
PENGCHU ZHANG* \\ Sandia National Laboratories, Department of Geochemistn', \\ MS 0750, Albuquerque, New Mexico 87185
}

JAMES A. RYAN

National Risk Management Research Laboraton: U.S. EPA. 5995 Center Hill Avenue, Cincinnati, Ohio 45224

Addition of phosphate to lead [Pb(II)]-contaminated soil to immobilize soil $\mathrm{Pb}$ by formation of pyromorphite has been proposed as an alternative remediation technique. Lead sulfate $\left(\mathrm{PbSO}_{4}\right.$, anglesite), a $\mathrm{Pb}$-bearing form found in contaminated soils and wastes, was reacted with a synthetic phosphate mineral, hydroxyapatite $\left[\mathrm{Ca}_{5}\left(\mathrm{PO}_{4}\right)_{3-}\right.$ $\mathrm{OHJ}$, under constant $\mathrm{pH}(\mathrm{pH} 2-7)$ and simulated gastric $\mathrm{pH}$ conditions (pH varied from 2 to 7 within $30 \mathrm{~min}$ ) to assess the effects of reaction kinetics on the formation rate of chloropyromorphite and the solubility of $\mathrm{Pb}$. Under constant pH condition, complete transformation of anglesite to chloropyromorphite, $\left[\mathrm{Pb}_{5}\left(\mathrm{PO}_{4}\right)_{3} \mathrm{Cl}\right]$, was obtained at $\mathrm{pH} 4$ and $\mathrm{pH} 5$. At $\mathrm{pH} 6$ and $\mathrm{pH} 7$, the newly formed chloropyromorphite precipitated on the surface of undissolved apatite. The coverage of the apatite surface may reduce apatite dissolution sate and the transformation rate of $\mathrm{Pb}$ from anglesite to chloropyromorphite. Increasing the $\mathrm{P} / \mathrm{Pb}$ ratio increased the transformation rate, but anglesite was still present after a 120-min reaction time. In the dynamic $\mathrm{pH}$ system, the added apatite was rapidly dissolved at the initial low $\mathrm{pH}$, and complete transformation of anglesite to chloropyromorphite was obtained within 25 min. The soluble $\mathrm{Pb}$ level was controlled by the solubility of chloropyromorphite during the entire reaction process. These results demonstrate the effect of reaction kinetics on the formation rate of chloropyromorphite and the mechanisms controlling the solubilization of $\mathrm{Pb}$ in the anglesite-apatite system. Furthermore, they illustrate that a complete transformation of ingested anglesite to chloropyromorphite can be achieved under gastrointestinal tract $\mathrm{pH}$ conditions if sufficient phosphate is provided.

\section{Introduction}

Lead-contaminated soils are a major source of $\mathrm{Pb}$ exposure to children through ingestion, respiratory, and dermal uptake. The relationship between soil $\mathrm{Pb}$ and blood $\mathrm{Pb}$ concentrations in children has been demonstrated, and it has been illustrated that the soil $\mathrm{Pb}$ species, specifically the mineralogical forms, is a factor in determining the bioavailability of soil $\mathrm{Pb}(1-3)$. Therefore, in assessing the risk of exposure to $\mathrm{Pb}$-contam-

* To whom correspondence should be addressed: telephone: (505)844-2669; fax: (505)844-7354; e-mail: pzhang@sandia.gov. inated soils, the geochemical forms of soil $\mathrm{Pb}$ should be considered. Furthermore, the concept of remediating $\mathrm{Pb}$ contaminated soil by transforming the labile soil $\mathrm{Pb}$ species, i.e., soluble and bioavailable species, into the $\mathrm{Pb}$ chemical form that is stable under the environmental and physiological conditions of exposure is desirable.

Current technologies for contaminated soil remediation are usually costly (4) and/or cannot permanently prohibit the toxic element from entering into the biosphere. Thus, as an altemative remediation technique, in-situ immobilization of Pb in contaminated soils with phosphate amendments has received a great deal of attention in the past several years $(4-11)$. This approach is based on the formation of geochemically stable lead phosphate minerals from the reactions of labile soil $\mathrm{Pb}$ forms with the added soluble phosphate salt or solid phosphate minerals such as apatite. Among the lead phosphate minerals, chloropyromorphite $\left[\mathrm{Pb}_{5}\left(\mathrm{PO}_{4}\right)_{3} \mathrm{Cl}\right]$ is the least soluble (12).

As the aqueous metal ions are recognized as the most mobile and bioaccessible species (13), the solubility of a metal species is generally an indication of its mobility, reactivity, and bioavailability. Reduction in bioavailability of soil $\mathrm{Pb}$ is akey issue in assessing the feasibility of in-situ immobilization of soil $\mathrm{Pb}$. Attenuation of $\mathrm{Pb}$ concentration in aqueous solutions and the solutions of $\mathrm{Pb}$-contaminated soils in the presence of hydrox]'apatite $\left[\mathrm{Ca}_{\mathbf{3}}\left(\mathrm{PO}_{4}\right)_{3} \mathrm{OH}\right]$ has been reported and is generally attributed to the formation of pyromorphite, $\mathrm{Pb}_{5}\left(\mathrm{PO}_{4}\right)_{3}(\mathrm{Cl}, \mathrm{OH}, \mathrm{F} . .$.$) , from the precipitation of soluble \mathrm{Pb}$ and phosphate $(6,9)$. In addition to the confirmation of reaction products from aqueous solutions, recent reports $(5$, 14) have presented direct evidences of formation of piromorphite in $\mathrm{Pb}$-contaminated soils amended with hydroxyapatite in suspension or in soil incubated-under environmental conditions.

However, solubility is a thermodynamic parameter and determines the soluble $\mathrm{Pb}$ level only when the system is at equilibrium. In a dynamic system, the soluble $\mathrm{Pb}$ concentration depends on the solid $\mathrm{Pb}$ form that has the highest dissolution rate but not necessarily the highest solubility. The in-vitro experiment conducted by Ruby and co-workers (15) to simulate chemical processes within the mammalian digestive tract found the dissolution rate of different $\mathrm{Pb}$ sources to be dependent upon $\mathrm{Pb}$ mineralogy', with slow rates of $\mathrm{Pb}$ dissolution resulting in decreased $\mathrm{Pb}$ bioavailability. Furthermore, in soil-apatite incubation experiments it was found that the rates of soil $\mathrm{Pb}$ fractions reacting with the added apatite varied (14), demonstrating the effect of composition of $\mathrm{Pb}$-bearing solids on the transformation rate of soil $\mathrm{Pb}$ species, and ultimately, on the bioavailability and mobility of soil $\mathrm{Pb}$ in a dynamic system. Thus, the transformation rate of soil $\mathrm{Pb}$ will vary with the dominant $\mathrm{Pb}$ bearing form(s) in the soil amended with phosphate, and therefore, the efficiency of transforming soil $\mathrm{Pb}$ into pyromorphite by addition of phosphate mineral will be dependent upon the dissolution rates of the solid $\mathrm{Pb}$-bearing forms in the soil and the added phosphate mineral as well as the rares of precipitation of pyromorphite.

In addition to the reaction occurring in soils, it has been speculated that the formation of pyromorphite may occur in the gastrointestinal tract (GI tract) when the contaminated soil is ingested with phosphate, thus successful reduction in soil $\mathrm{Pb}$ bioavailability requires a rapid and complete conversion of the chemically and/or biologically reactive $\mathrm{Pb}$ forms into pyromorphite. The dissolution rates of $\mathrm{Pb}$-bearing forms and the amended phosphate mineral determine the rates of soluble $\mathrm{Pb}$ and phosphate $\left(\mathrm{PO}_{4}\right)$ released into solution, and 
thus the rate of formation of pyromorphite. As the $\mathrm{pH}$ in GI tract varies rapidly with time after ingestion of a material, it is important to understand the effect of $\mathrm{pH}$ on the dissolution of $\mathrm{Pb}$ and phosphate minerals in relation to the precipitation rate of pyromorphite.

Anglesite, a secondary $\mathrm{Pb}$ mineral mainly resulting from weathering of galena (PbS) in acidic environment (16), is commoniy found in mine wastes and soils (2). The bioavailability of $\mathrm{Pb}$ in anglesite-contaminated soils has been speculated to be determined by kinetic constraints, e.g., the dissolution rate, which controls the $\mathrm{Pb}$ solubilization $(1,2$, $17,18)$. To evaluate the reduction in bioavailability of anglesite in the presence of phosphate, anglesite and a synthetic hydroxyapatite were reacted under $\mathrm{pH}$ conditions found in the gastrointestinal fluid ( $\mathrm{pH} \mathrm{2-7)}$ to assess the dissolution rate of the two minerals, the formation rate of pyromorphite, and the mechanism(s) that control(s) the $\mathrm{Pb}$ solubilin during the reaction.

\section{Methods}

pH of Interest. The pH range of $2-7$ was selected to simulate the $\mathrm{pH}$ values in the GI tract that has been diseussed elsewhere (19). Reactions were carried out under static $\mathrm{pH}$ condition ( $\mathrm{pH}$-constant) and in suspensions in which the $\mathrm{pH}$ was adjusted from 2 to 7 within $30 \mathrm{~min}$ (pH-dynamic). This $\mathrm{pH}$-dynamic system simulated the $\mathrm{pH}$ reactions in the GI tract and allowed determination of the potential transformation of $\mathrm{Pb}$ from anglesite to pyromorphite if anglesite and apatite were ingested simultaneously. It should be pointed out that the selection of $\mathrm{pH}$ range and time scale used was based on human physiology, but the results obtained can be applied to other reaction systems such as soil solutions and waste treatments.

Dissolution of Hydroxyapatite and Anglesite. Dissolution of anglesite and aparite was conducted in a 1.1-L glass beaker that contained a glass $\mathrm{pH}$ electrode and a stirring paddle. The beaker was placed in a water bath with a constant temperature of $37^{\circ} \mathrm{C}$. An automatic titrator was used to adjust and maintain the suspension $\mathrm{pH}$ with $0.1 \mathrm{~N} \mathrm{NaOH}$ and $0.1 \mathrm{~N} \mathrm{HNO}_{3}$ solutions. One liter $(1.0 \mathrm{~L})$ solution of 0.100 $\mathrm{M} \mathrm{NaNO}_{3}$ and $0.001 \mathrm{M} \mathrm{NaCl}$ was adjusted to a desired $\mathrm{pH}$ prior to mineral addition. After mineral addition, the suspension was maintained at a constant $\mathrm{pH}$ and sampled periodically for $2-3 \mathrm{~h}$. The suspension samples were filtered with a 0.2- $1 \mathrm{~m}$ membrane and analyzed for $\mathrm{PO}_{4}, \mathrm{SO}_{4}, \mathrm{Ca}$, and $\mathrm{Pb}$ concentrations on an inductively coupled plasma spectrophotometer.

The symthetic hydroxyapatite used in this experiment was obtained from Bio-Rad. It has a specific surface area of 67.3 $\mathrm{m}^{2} \mathrm{~g}^{-1}$ by BET nitrogen absorption and a $\mathrm{P} / \mathrm{Ca}$ molar ratio of 1.62, which is close to the ideal ratio of 1.67. One to three grams $(1.00-3.00 \mathrm{~g})$ of apatite was used for dissolution rate determination. The dissolution of apatite was determined by measuring the soluble $\mathrm{Ca}$ and $\mathrm{PO}_{4}$ concentrations as a function of reaction time.

The reagent lead suifate $\left(\mathrm{PbSO}_{4}\right.$, obtained from Fisher Scientific) was examined by X-ray diffraction (XRD) analysis. The $X R D$ patterns indicates that the solid is pure anglesite. A specific surface area of $0.9 \mathrm{~m}^{2} \mathrm{~g}^{-1}$ was obtained by BET nitrogen absorption. One gram (1.000 g) of anglesite was used for dissolution rate determination. Soluble $\mathrm{Pb}$ and $\mathrm{SO}_{4}$ concentrations were measured as a function of time to determine the dissolution of anglesite.

Reaction between Apatite and Anglesite. Determination of the kinerics of the apatite-anglesite reaction was conducted in the same reactor used in dissolution study. The amount of anglesite used to react with apatite was $1.5 \times 10^{-5}$ mol, which was three times the anglesite solubility. Samples were periodically taken during the 120-min reaction period.
In the $\mathrm{pH}$-constant study, the $\mathrm{pH}$ was adjusted to $2,3,4$, 5,6 , or 7 and held constant for the 120 -min reaction period. The amount of hydroxyapatite used was based on the molar ratio of phosphate to lead ( $\mathrm{P} / \mathrm{Pb})$, with ratios of $3 / 5,6 / 5$, and $9 / 5$ being used. These corresponded to 1,2 , and 3 times the amount of phosphate needed to transform the added $\mathrm{Pb}$ from anglesite into pyromorphite based on the $3 / 5 \mathrm{P} / \mathrm{Pb}$ ratio of chloropyromorphite, $\mathrm{Pb}_{5}\left(\mathrm{PO}_{4}\right)_{3} \mathrm{Cl}$. The sampled suspensions were filtered with a $0.2-\mu \mathrm{m}$ membrane and analyzed for soluble $\mathrm{Ca}, \mathrm{PO}_{4}, \mathrm{~Pb}$, and $\mathrm{SO}_{4}$ concentrations.

In the $\mathrm{pH}$-dynamic study, anglesite was reacted with apatite at a $\mathrm{P} / \mathrm{Pb}$ molar ratio of $4.5 / 5$. The solution $\mathrm{pH}$ was adjusted in increments of one $\mathrm{pH}$ unit from 2 to 7 over a 30 -min time interval and then maintained at a $\mathrm{pH}$ of 7 for an additional $30 \mathrm{~min}$. The suspension was sampled twice at each pH of $2,3,4,5,6$, and 7 . One sample was taken 1 min after the desired $\mathrm{pH}$ was established, and the second sample was taken before the $\mathrm{pH}$ was adjusted to the next $\mathrm{pH}$ value. The sampled suspensions were filtered with a $0.2-1 / \mathrm{m}$ membrane and analyzed for soluble $\mathrm{Ca}, \mathrm{PO}_{4}, \mathrm{~Pb}$, and $\mathrm{SO}_{4}$ concentrations.

In addition to the analysis of solution constituents, the solids in the reactor were collected by passing the reacied suspension through a $0.45-\mu \mathrm{m}$ membrane. The solids were examined by XRD and scanning electronic microscope coupled with X-ray energy dispersive spectroscopy (SEM/) EDS) for identification of minerals and the surface morphology and elemental composition.

Analytical Procedures. The soluble $\mathrm{Ca}, \mathrm{PO}_{4}, \mathrm{~Pb}$, and $\mathrm{SO}_{4}$ concentrations were determined with an inductively coupled plasma spectrophotometer (ICP, Trace 61E, Thermal Jerrel Ash). The detection limit for the four elements was $2 / \mathrm{g} \mathrm{L}^{-1}$. The U.S. EPA Water Supply Performance Evaluation Study' (WSO33) solution was used as the calibration standard. Experimental blanks, standards, and spiked samples were used for analytical quality control. Solution and suspension $\mathrm{pH}$ was measured by a glass $\mathrm{pH}$ electrode that was connected to a Mettler titrator. With this setup, the variation of $\mathrm{pH}$ could be maintained within $0.01 \mathrm{pH}$ unit.

The solid samples were examined with an X-ray diffractometer (Scintag, XDS 2000; Cu Ka radiation, a potential of $30 \mathrm{kV}$ filament current of $20 \mathrm{~mA}$ ) and step-scanning at $0.04^{\circ}$ $2 \theta / \mathrm{s}$ was employed to obtain the XRD patterns for the powder samples. A scanning electron microscope coupled with energy-dispersive X-ray spectroscope (SEM/EDX, JEOL, JSM 5300) was used to obtain the solid images and elemental composition for the solids coated with carbon or gold.

A computer code for geochemical modeling of aqueous system, EQ3/6 (version 7.0), was used to estimate the species distribution for $\mathrm{Pb}(\mathrm{II}), \mathrm{SO}_{4}, \mathrm{Ca}, \mathrm{Cl}$, and $\mathrm{PO}_{4}$ and the degree of saturation in the suspension (24).

\section{Results}

Dissolution Rate of Hydroxyapatite and Anglesite. Dis: solution rate of apatite was determined by measuring the concentrations of soluble $\mathrm{PO}_{4}$ and $\mathrm{Ca}$ concentrations r's reaction time (Figure 1). The dissolution rate increases with decreasing $\mathrm{pH}$, and below $\mathrm{pH} 4$, the dissolution was too rapid to be accurately determined under these experimental conditions. Furthermore, a constant $\mathrm{pH}$ could not be maintained because of the rapid consumption of $\mathrm{H}^{+}$during dissolution:

$$
\mathrm{Ca}_{5}\left(\mathrm{PO}_{4}\right)_{3} \mathrm{OH}(\mathrm{s})+7 \mathrm{H}^{+} \Rightarrow 5 \mathrm{Ca}^{2+\dot{+}}+3 \mathrm{H}_{2} \mathrm{PO}_{4}{ }^{2-}+\mathrm{H}_{2} \mathrm{O}
$$

At $\mathrm{pH} 4,1.2( \pm 0.2) \mathrm{g}$ of added apatite dissolved within 80 min, resulting in a solution of $1.2 \pm 0.2 \times 10^{-2} \mathrm{M} \mathrm{Ca}$ and 7.2 $\pm 1.1 \times 10^{-3} \mathrm{M} \mathrm{PO}_{4}$. Based on the dissolution reaction (eq I), these concentrations gave an activity product of $10^{14=1.2}$, which is close to the published solubility product $\left(K_{\mathrm{sp}}\right)$ of 


\section{DISCLAIMER}

This report was prepared as an account of work sponsored by an agency of the United States Government. Neither the United States Government nor any agency thereof, nor any of their employees, make any warranty, express or implied, or assumes any legal liability or responsibility for the accuracy, completeness, or usefulness of any information, apparatus, product, or process disclosed, or represents that its use would not infringe privately owned rights. Reference herein to any specific commercial product, process, or service by trade name, trademark, manufacturer, or otherwise does not necessarily constitute or imply its endorsement, recommendation, or favoring by the United States Government or any agency thereof. The views and opinions of authors expressed herein do not necessarily state or reflect those of the United States Government or any agency thereof. 


\section{DISCLAIMER}

Portions of this document may be illegible in electronic image products. Images are produced from the best available original document. 


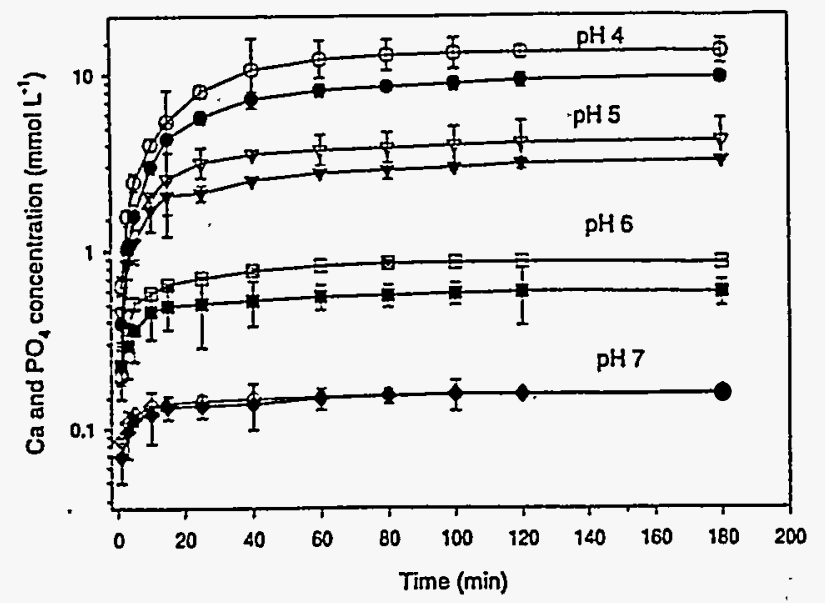

FIGURE 1. Dissolution of hydroxyapatite as a function of time and $\mathrm{pH}$. The filled and unfilled symbols represent the phosphate and calcium concentrations, respectively. The error bars indicate the standard deviations of experimental replication.

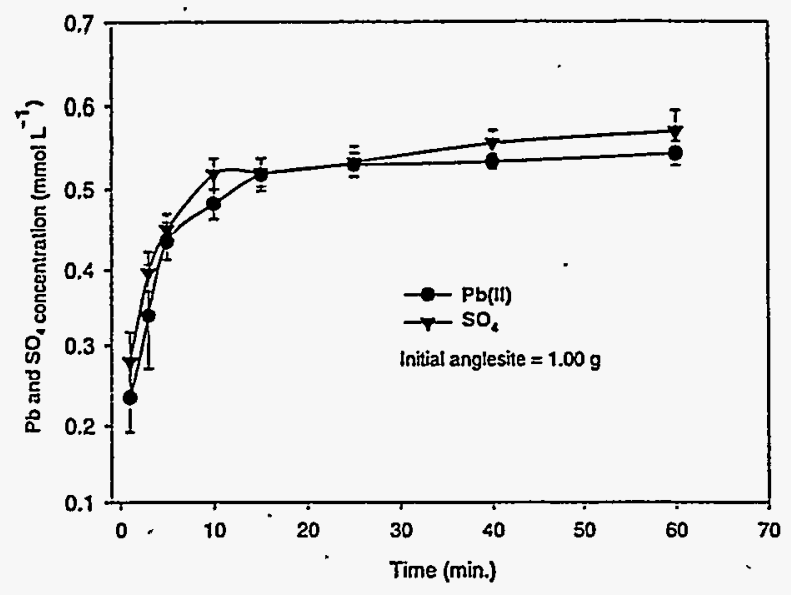

FIGURE 2. Dissolution of anglesite as a function of time. The data are averaged from anglesite dissolution occurring in the solutions with $\mathrm{pH}$ from 2 to 7 . The error bars indicate the standard deviations of experimental replication.

$10^{15.8=1.7}(20)$. Thus, the solution was saturated with respect to apatite. At the relatively high $\mathrm{pH}$ values, e.g., $\mathrm{pH} 6$ and $\mathrm{pH} 7$, the dissolved $\mathrm{Ca}$ and $\mathrm{PO}_{4}$ concentrations reached steady state in a shorter time period. This might be attributed to the effect of the total surface area of the solid apatite on dissolution rate. At $\mathrm{pH} 6$ and $\mathrm{pH} 7$, dissolution of apatite did not substantially reduced the added apatite surface area, only 1 and $4 \%$ of the total added mineral were dissolved at $\mathrm{pH} 7$ and $\mathrm{pH} 6$ within $60 \mathrm{~min}$, respectively. In contrast, 20 and $40 \%$ of added apatite were dissolved at $\mathrm{pH} 5$ and $\mathrm{pH} 4$ within $25 \mathrm{~min}$.

The soluble species compositions at $\mathrm{pH} 4, \mathrm{pH} 5$, and even $\mathrm{pH} 6$ were stoichiometrically similar to that in apatite with a P/Ca molar ratio of $3 / 5$ (Figure 1). However, at $\mathrm{pH} 7$ the $\mathrm{PO}_{4}$ and $\mathrm{Ca}$ concentrations were essentially the same. This can be attributed to $\mathrm{Ca}^{2 \div}$ adsorption on the undissolved apatite surface, which became negatively charged with increasing $\mathrm{pH}$. Adsorption of $\mathrm{Ca}^{2+}$ reduced the soluble $\mathrm{Ca}$ concentration, causing the composition of soluble species to no longer be stoichiometric with respect to apatite.

In contrast to hydroxyapatite, dissolution of anglesite is independent of $\mathrm{pH}$ within the $\mathrm{pH}$ range of $2-7$ (Figure 2). The dissolution of anglesite is a rapid process with saturation being reached within $20 \mathrm{~min}$ and about $45-55 \%$ of saruration concentration observed within the initial $3 \mathrm{~min}$ (Figure 2). Soluble $\mathrm{Pb}$ and $\mathrm{SO}_{4}$ concentrations in the anglesite suspension vs reaction time indicated there was no significant effects of $\mathrm{pH}$ on dissolution in the $\mathrm{pH}$ range of $2-7(P=0.05)$ or on the stoichoimetric composition of the soluble species. Thus dissolution of anglesite follows the reaction:

$$
\mathrm{PbSO}_{4}(\mathrm{~s})-\mathrm{Pb}^{2+}(\mathrm{aq}) \div \mathrm{SO}_{4}^{2-}(\mathrm{aq})
$$

At 60-min reaction, the activity product of $\mathrm{Pb}^{2+}$ and $\mathrm{SO}_{4}{ }^{2-}$ was $10^{-7.3}$, which is very close to its reported solubility product, $K_{\mathrm{sp}}=10^{-7.8}(21)$. This implies little influence of adsorption or retention of dissolved ions by the anglesite, which has a low specific surface area of $0.9 \mathrm{~m}^{2} \mathrm{~g}^{-1}$.

Reactions of Anglesite and Hydroxyapatite. It has been demonstrated that the dominant reaction in an aqueous system containing $\mathrm{Pb}^{2+}$ and soluble $\mathrm{PO}_{4}$ is the formation of pyromorphite $(6,11,22,23)$. The product will be chloropyromorphite $\left[\mathrm{Pb}_{5}(\mathrm{PO} 4)_{3} \mathrm{Cl}\right]$ if $\mathrm{Cl}^{-}$is present in the aqueous phase. The results from previous experiments conducted in our laboratory have demonstrated that the formation of chloropyromorphite is a rapid process, completed within seconds. Therefore, the formation of chloropyromorphite is favorable in a $\mathrm{PO}_{4}-\mathrm{Pb}-\mathrm{H}_{2} \mathrm{O}$ system, both thermodynamically and kinetically.

Considering chloropyromorphite formation from soluble $\mathrm{Pb}$ and $\mathrm{PO}_{4}$ is instantaneous, the dissolution of hydroxjapatite and/or anglesite should be the rate-limiting factor in the overall reaction:

$$
\begin{aligned}
\mathrm{Ca}_{5}\left(\mathrm{PO}_{4}\right)_{3} \mathrm{OH}(\mathrm{s})+5 \mathrm{PbSO}_{4}(\mathrm{~s})+\mathrm{Cl}^{-}+\mathrm{H}^{+}= \\
\mathrm{Pb}_{5}\left(\mathrm{PO}_{4}\right)_{3} \mathrm{Cl}(\mathrm{s})+5 \mathrm{Ca}^{2+}+5 \mathrm{SO}_{4}{ }^{2-}+\mathrm{H}_{2} \mathrm{O}
\end{aligned}
$$

Measurement of the concentrations of soluble species as a function of reaction time was the primary means of determining the reaction progress. The components dissolved from anglesite or apatite can be used to indicate the dissolution rates of the two minerals if they are not removed from solution during reaction. The distribution of species modeled from a geochemical computer code, EQ3 (24), indicated that the solutions were far from saturation for any possible calcium sulfate minerals. Thus, the total concentrations of $\mathrm{Ca}$ and $\mathrm{SO}_{4}$ in solutions can be used to determine the dissolution of hydroxyapatite and anglesite, respectively. The differences between the dissolved and the measured $\mathrm{PO}_{4}$ and $\mathrm{Pb}^{2+}$ were attributed to precipitation of chloropyromorphite.

pH-Constant Study. The concentrations of soluble $\mathrm{Ca}$, $\mathrm{SO}_{4}, \mathrm{~Pb}$, and $\mathrm{PO}_{4}$ as a function of time were used to illustrate the dissolution rates of apatite and anglesite as well as the formation of chloropyromorphite. The concentrations of $\mathrm{Ca}$ and $\mathrm{PO}_{4}, 1.43$ and $0.9 \mathrm{mmol} \mathrm{L^{-1 }}$ at $\mathrm{pH} 2$ after 10-min reaction, indicated complete dissolution of the added apatite (Figure $3 \mathrm{a}$ ). The soluble $\mathrm{Pb}$ and $\mathrm{SO}_{4}$ concentrations increased with time at nearly equivalent rates, implying that no dissolved $\mathrm{Pb}$ was removed from the solution. The concentrations of soluble $\mathrm{Pb}$ and $\mathrm{SO}_{4}$ in the solution (Figure $3 \mathrm{a}$ ) were approximately equivalent to that determined from suspension containing only anglesite (Figure 2). Apparently, the solution reached saturation with respect to anglesite but not chloropyromorphite. The results from the XRD analysis of the solids showed no detectable chloropyromorphite was formed after 120-min reaction, and the predominant mineral was the added anglesite (Figure $4 \mathrm{a}$ ).

Complete dissolution of apatite was achieved within 10 min at $\mathrm{pH} 3$ (Figure $3 \mathrm{~b}$ ). The soluble $\mathrm{SO}_{4}$ and $\mathrm{Pb}$ concentrations were 1.0 and $0.1 \mathrm{mmol} \mathrm{L}^{-1}$, respectively, indicating that $0.9 \mathrm{mmol}$ of dissolved $\mathrm{Pb}$ was precipitated during the 10min reaction time. The soluble $\mathrm{PO}_{4}$ concentration was about $0.4 \mathrm{mmol} \mathrm{L}^{-1}$, which suggested that about $0.5 \mathrm{mmol}$ of $\mathrm{PO}_{4}$ was removed from the solution. This amount of $\mathrm{PO}_{4}$ was equivalent to that needed to precipitate the $0.9 \mathrm{mmol}$ of dissolved $\mathrm{Pb}$ as chloropyromorphite. The formation of 

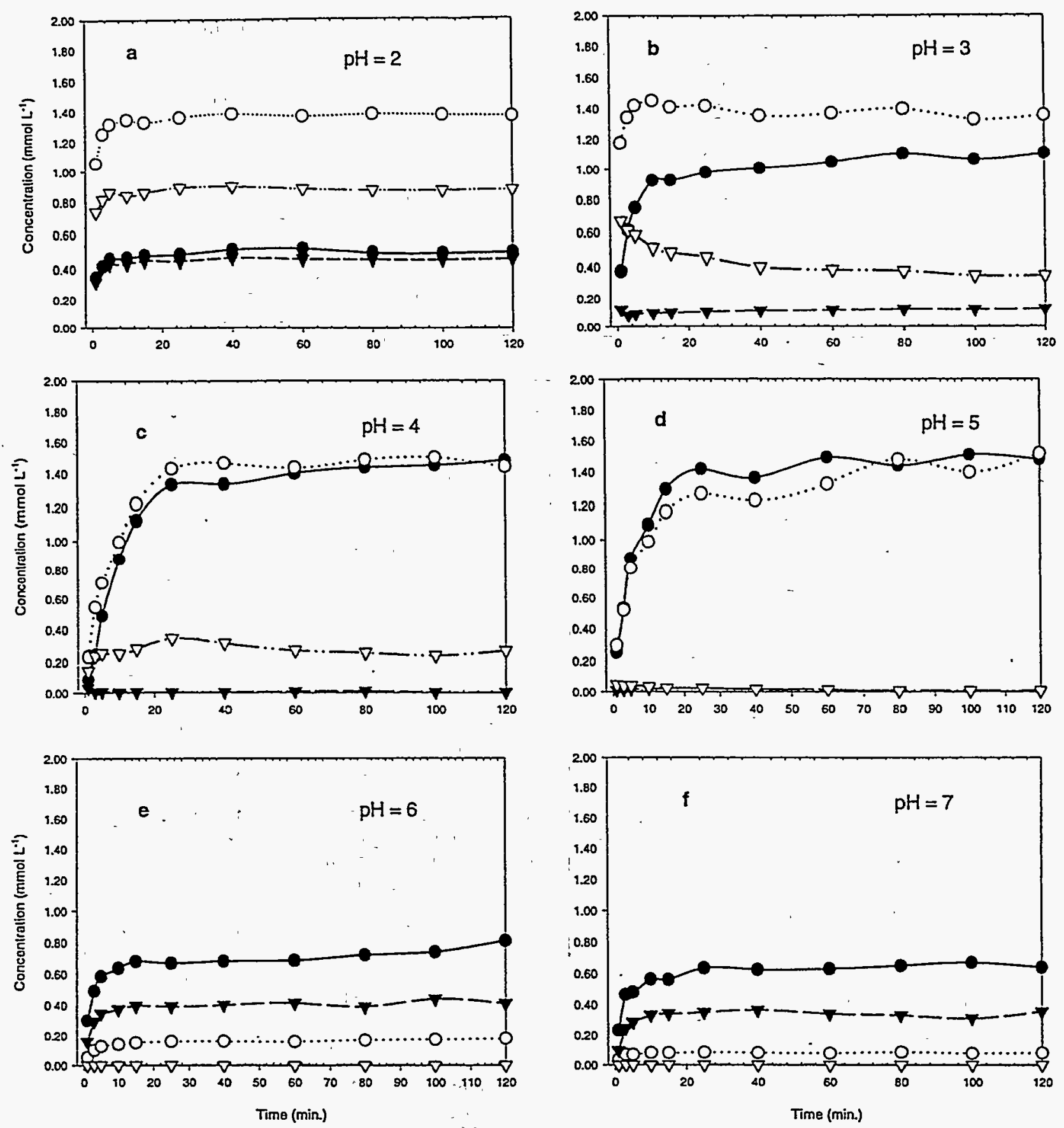

$$
\rightarrow \mathrm{SO}_{4} \quad \cdots \mathrm{O} \mathrm{Ca} \quad \rightarrow-\mathrm{Pb} \quad \rightarrow \cdots \mathrm{PO}_{4}
$$

FIGURE 3. Concentrations of the soluble $\mathrm{Pb}_{4} \mathrm{SO}_{4}, \mathrm{Ca}$, and $\mathrm{PO}_{4}$ in the anglesite-hydroxyapatite suspensions as a function of time. The $\mathrm{P} / \mathrm{Pb}$ ratio in the suspensions was $3 / 5$. Dissolution of anglesite and hydroxyapatite can be estimated from the soluble $\mathrm{SO}_{4}$ and $\mathrm{Ca}_{\mathrm{a}}$ concentrations, respectively.

chloropyromorphite was confirmed by the XRD patterns for the solid reacting at $\mathrm{pH} 3$ (Figure $4 \mathrm{~b}$ ). The XRD patterns also indicated that anglesite was present and thus had not been fully transformed to chloropyromorphite.

Dissolution of apatite and anglesite at $\mathrm{pH} 4$ (Figure 3c) was $100 \%$ and $95 \%$, respectively, within $25 \mathrm{~min}$. The soluble $\mathrm{Pb}$ was below $10^{-6} \mathrm{~mol} \mathrm{~L} \mathrm{~L}^{-1}$ after $20 \mathrm{~min}$, while the soluble $\mathrm{PO}_{4}$ level was maintained at the level of $10^{-4} \mathrm{~mol} \mathrm{~L}^{-1}$ after $5 \mathrm{~min}$. The XRD patterns of the solids indicate that both anglesite and chloropyromorphite are present but that there is nearly a complete transformation of anglesite- $\mathrm{Pb}$ into chloropyromorphite- $\mathrm{Pb}$ (Figure 4c). Similarly, at $\mathrm{pH}$, approximately $95 \%$ of anglesite was dissolved within $20-\mathrm{min}$ reaction (Figure $3 \mathrm{~d}$ ), and chloropyromorphite was the oniy mineral identified in the reacted solid after 120 -min reaction (Figure 4d). Thus, complete transformation of $\mathrm{Pb}$ from anglesite to chloropyromorphite was achieved.

In contrast, the dissolution rates of hydroxyapatite at $\mathrm{pH}$ 6 and $\mathrm{pH} 7$ were low, as demonstrated in Figure 3, panels $e$ and $f$, respectively. The soluble $\mathrm{PO}_{4}$ concentrations were insufficient to saturate the solution with respect to chloropyromorphite, even though the solution was rapidly saturated with respect to anglesite, whose dissolution rate was not $\mathrm{pH}$ dependent (Figure 2). This resulted in a very limited transformation of anglesite to chloropyromorphite during the $120-\mathrm{min}$ reaction time. Furthermore, as the apatite surface became more negatively charged with increasing $\mathrm{pH}$, $\mathrm{Pb}^{2+}$ was adsorbed from solution and chloropyromorphite 


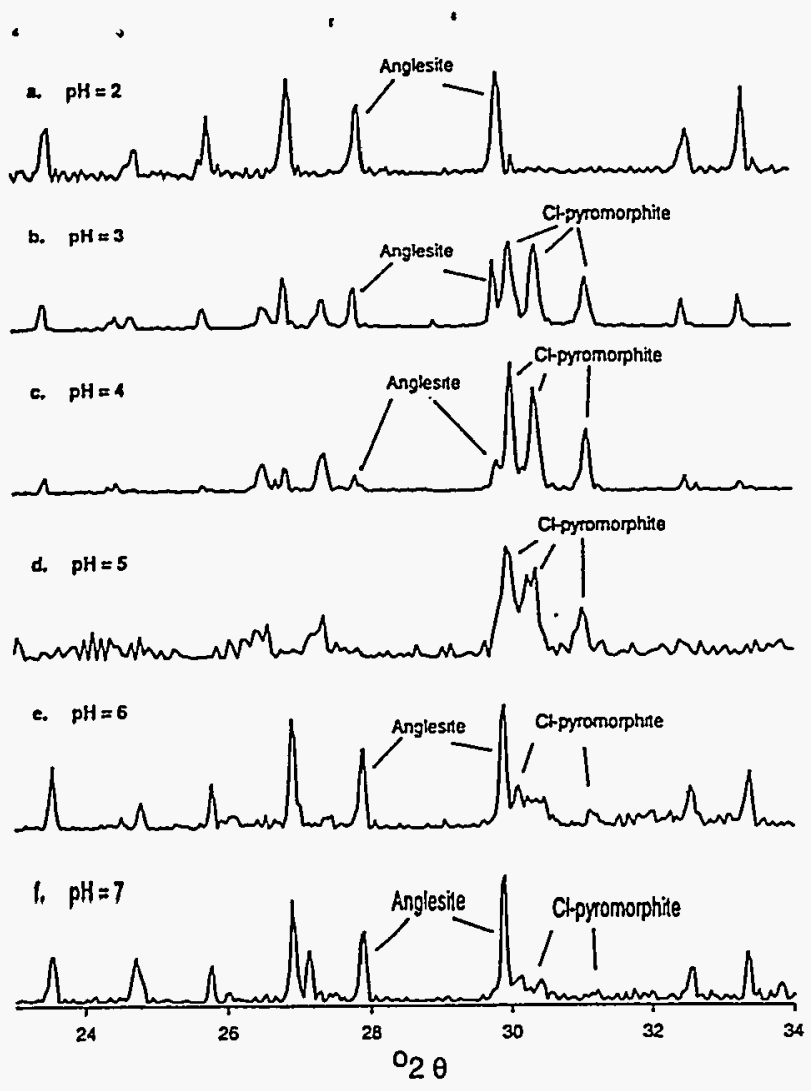

FIGURE 4. XRD patterns for solids collected from the anglesitehydroxyapatite suspensions with $\mathrm{pH}$ after 120 min reaction, $\mathrm{P} / \mathrm{Pb}=3 / 5$.

formed on the apatite surface (Figure 6b). The surface reaction may decrease or prevent apatite from further dissolution (23) and, therefore, reduces the formation rate of chloropyromorphite in the system. Consequently, the soluble $\mathrm{Pb}$ concentration at $\mathrm{pH} 6$ and $\mathrm{pH} 7$ was controlled by the solubility of anglesite (Figure 3, panels $e$ and $f$. The XRD peaks for solids collected from anglesite-apatite suspensions at $\mathrm{pH} 6$ and $\mathrm{pH} 7$ confirmed limited formation of chloropyromorphite and that the added anglesite was the predominant mineral in the solid (Figure 4, panels $e$ and $f$ ).

Effect of $\mathrm{P} / \mathrm{Pb}$ Ratios. Similar results were observed in the suspensions with $\mathrm{P} / \mathrm{Pb}=6 / 5$ and $9 / 5$, as described in detail for $\mathrm{P} / \mathrm{Pb}=3 / 5$ (Figures 3 and 4 ). To illustrate the effects of $\mathrm{P} / \mathrm{Pb}$ ratios on the transformation rate of anglesite to chloropyromorphite and soluble $\mathrm{Pb}$ level in the apatiteanglesite systems, the results obtained after 120 -min reaction from these three $\mathrm{P} / \mathrm{Pb}$ ratios are presented together in Figure 5. The transformation of anglesite to chloropyromorphite was incomplete at low (pH 2 and 3) and high (pH 6 and 7) $\mathrm{pH}$ values for these three $\mathrm{P} / \mathrm{Pb}$ ratios. The increase in $\mathrm{P} / \mathrm{Pb}$ ratio increased the conversion of anglesite to chloropyromorphite, implying that soluble $\mathrm{PO}_{4}$ was the limiting reactant and that the dissolution of apatite was the rate-limiting factor. At the intermediate $\mathrm{pH}$ values ( $\mathrm{pH} 4$ and 5), there was essentially complete conversion of anglesite to chloropyromorphite for all $\mathrm{P} / \mathrm{Pb}$ ratios (Figure 5).

Effect of Solid Surface. In addition to the direct effect of dissolution rates of anglesite and aparite on the transformation process, the influence of the mineral surface on the reaction was also observed. At low $\mathrm{pH}$ values, the dissolution of apatite was rapid, and complete dissolution was achieved within $10 \mathrm{~min}$ (Figure 3a,b). Chloropyromorphite was observed to form in the solution at $\mathrm{pH} 3$ (Figure 6a). In contrast, the dissolution rate of apatite is slow at $\mathrm{pH}$ 6 and $\mathrm{pH} 7$, and the undissolved hydroxyapatite provided a - surface for $\mathrm{Pb}^{2+}$ adsorption from solution. Furthermore, the hydroxyapatite surface served as the host for nucleation of
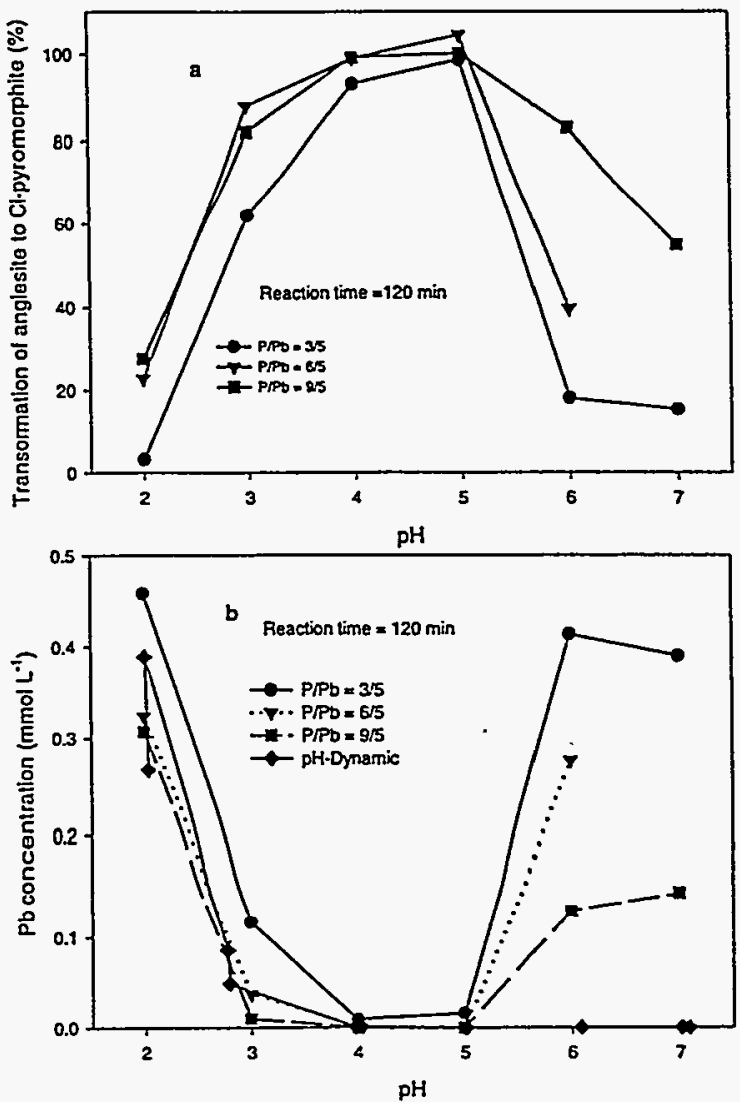

FIGURE 5. Effects of $\mathrm{pH}$ on dissolution of anglesite and transformation of $\mathrm{Pb}(11)$ from anglesite into chloropyromorphite in anglesitehydroxyapatite suspensions (a) and on the soluble $\mathrm{Pb}$ (II) concentrations (b) after $120 \mathrm{~min}$ reaction for each of the three $\mathrm{P} / \mathrm{Pb}$ ratios.

chloropyromorphite $(23,25)$. The fine needle-shaped chloropyromorphite (confirmed by EDS) coated the surface of apatite in the suspension at $\mathrm{pH} 6$ after 120 -min reaction (Figure 6b). This coating might further reduce the dissolution rate of hydroxyapatite and result in reduction in the transformation rate of $\mathrm{Pb}$ from anglesite to chloropyromorphite.

$\mathrm{pH}-$ Dynamic Study. For the reaction conducted with $\mathrm{pH}$ varying from 2 to 7 , the added hydroxyapatite $(0.22 \mathrm{~g})$ was completely dissolved during the first $5 \mathrm{~min}$, and a high soluble $\mathrm{PO}_{4}$ concentration $\left(1.3 \times 10^{-3} \mathrm{M}\right)$ was established at the initial low pH (Figure 7). The soluble $\mathrm{PO}_{4}$ concentration then decreased with time and $\mathrm{pH}$ and stayed stable at 2-3 $\times 10^{-4} \mathrm{M}$ after $20 \mathrm{~min}$ (Figure 7). Because of the availability of soluble $\mathrm{PO}_{4}$, the dissolved $\mathrm{Pb}$ from anglesite was rapidly precipitated into chloropyromorphite and the soluble $\mathrm{Pb}$ concentration quickly decreased from $4 \times 10^{-4} \mathrm{~mol} \mathrm{~L}^{-1}$ at $\mathrm{pH} 2$ to $10^{-7} \mathrm{~mol} \mathrm{~L}^{-1}$ within $5 \mathrm{~min}$, at $\mathrm{pH}$ 3. The soluble- $\mathrm{Pb}$ concentration remained at $10^{-8} \mathrm{M}$ thereafter. Complete anglesite dissolution was achieved between 20 and $25 \mathrm{~min}$, as indicated by the soluble $\mathrm{SO}_{4}$ concentration (Figure 7). The lack of $\mathrm{Pb}$ and $\mathrm{PO}_{4}$ in solution suggests a complete transformation of $\mathrm{Pb}$ from anglesite into chloropyromorphite during this time period. With increasing $\mathrm{pH}$, the dissolved aparite might have reprecipitated from solution, causing a decrease in the soluble phosphate level. Slightly decreasing Ca concentration, ranging from 1.8 to $2.1 \times 10^{-3} \mathrm{~mol} \mathrm{~L}^{-1}$, with increasing $\mathrm{pH}$ and time implies limited precipitation of apatite from the dissolved $\mathrm{Ca}$ and $\mathrm{PO}_{4}$ could occur when the suspension $\mathrm{pH}$ increased. However, the only mineral in the reacted solid identified by XRD analysis after $120 \mathrm{~min}$ was chloropyromorphite (not shown). Therefore, more than $90 \%$ of phosphate removed from solution was consumed by precipitation of $\mathrm{Pb}$ as chloropyromorphite. 
a

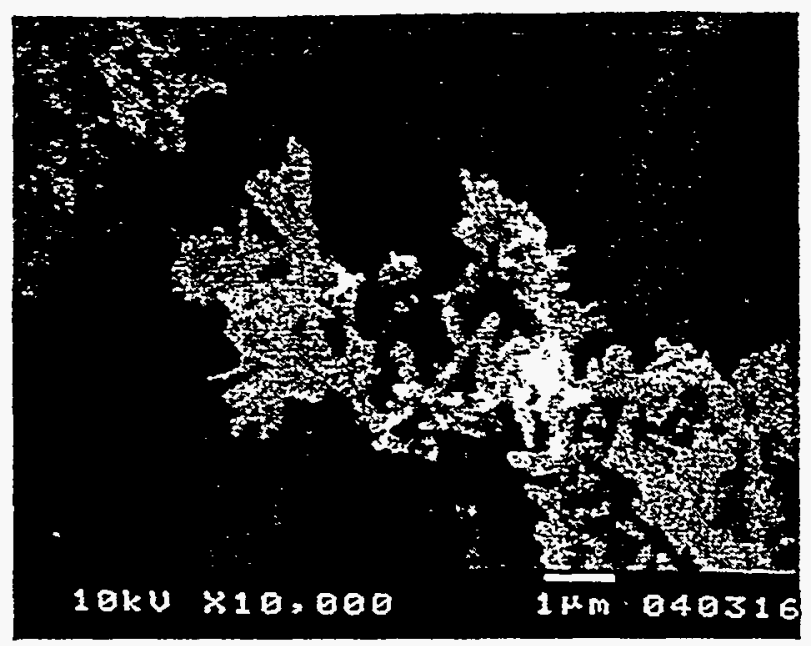

b

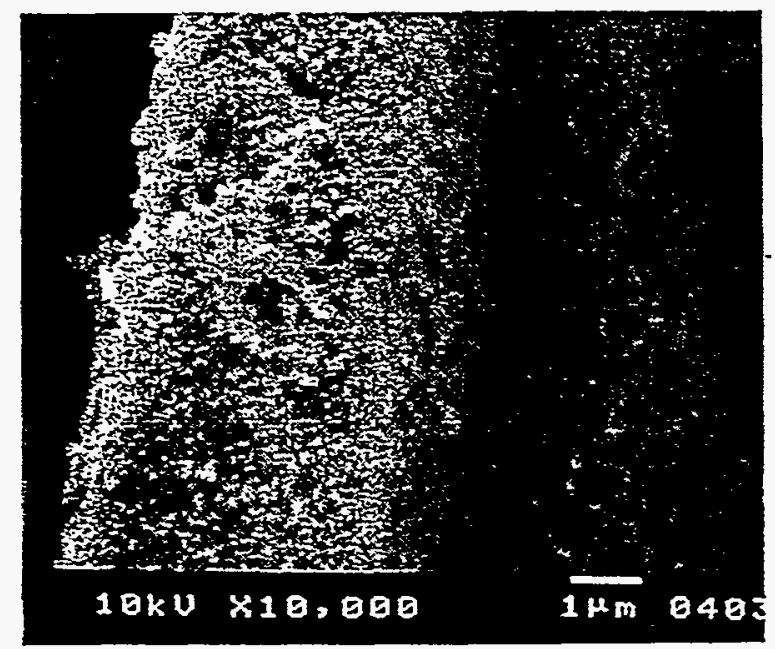

FIGURE 6. SEM images for the solids collected from the anglesitehydroxyapatite suspensions at $\mathrm{pH} 3(\mathrm{a}$ ) and $\mathrm{pH} 6$ (b). The precipitate of chloropyromorphite occurred in solution at $\mathrm{pH} 3$. At pH 6, the surface of undissolved apatite was covered by the precipitate, which may reduce the dissolution rate of apatite.

\section{Discussion}

The effects of solution $\mathrm{pH}$ on transformation of anglesite to chloropyromorphite and the soluble $\mathrm{Pb}$ level are attributed to the $\mathrm{pH}$ dependence of the solubility of chloropyromorphite and the dissolution rate of hydroxyapatite. At low $\mathrm{pH}$ values, the solubility of $\mathrm{Pb}$ from chloropyromorphite is comparable with that of anglesite. The solution might at irrst be saturated with respect to anglesite. For example, at $\mathrm{pH} 2$, the soluble phosphate concentration from the added apatite at $\mathrm{P} / \mathrm{Pb}$ of $3 / 5$ is lower than $10^{-3} \mathrm{M}$, thus, the soluble $\mathrm{Pb}$ activity has to be $10^{-35}$ or higher in order to saturate the solution with respect to chloropyromorphite (20), while it is only $10^{-3.89}$ for anglesite (Figure 2). Thus, the solution is saturated with respect to anglesite, and the soluble $\mathrm{Pb}$ concentration is determined by the solubility of anglesite (Figure $5 \mathrm{~b}$ ). Accordingly, precipitation of chloropyromorphite under these conditions was limited. About $35 \%$ of added anglesite was dissolved at $\mathrm{pH} 2$, and this was equal to that found in the suspension containing only anglesite, as shown in Figure 2. As the amount of apatite is increased to $\mathrm{P} / \mathrm{Pb}$ ratios of $6 / 5$ and $9 / 5$, the soluble $\mathrm{PO}_{4}$ concentration would be 1.8 and 2.7 $\times 10^{-3} \mathrm{M}$, respectively, assuming complete dissolution of the added apatite. These soluble $\mathrm{PO}_{4}$ levels saturated the solutions with respect to chloropyromorphite and resulted

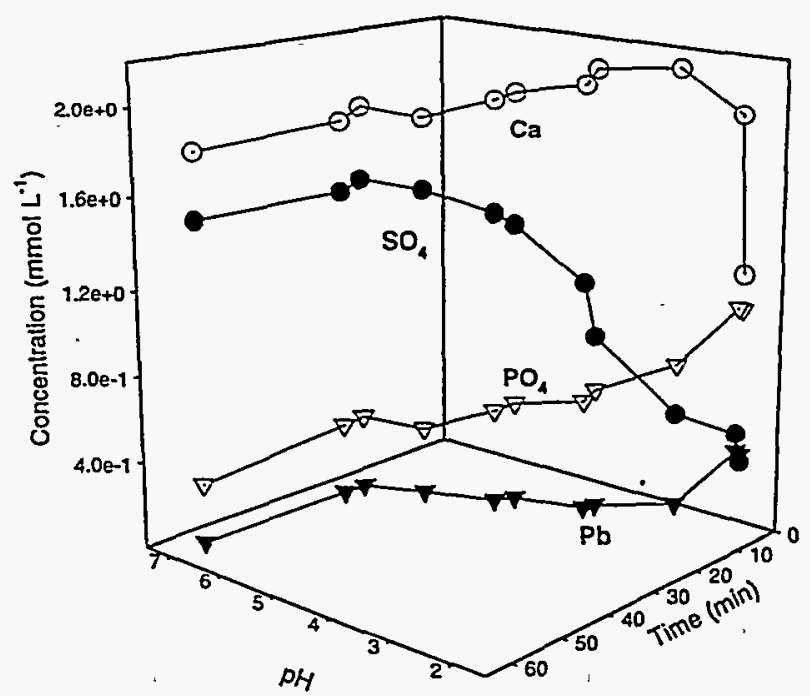

FIGURE 7. Effects of $\mathrm{pH}$ and reaction time on the concentrations of soluble species in the anglesite-hydroxyapatite system. The soluble $\mathrm{SO}_{4}$ and $\mathrm{Ca}$ can be used to estimate the dissolution of anglesite and apatite, respectively. The difference between the soluble $\mathrm{SO}_{4}$ and $\mathrm{Pb}$ is attributed to the precipitation of chloropyromorphite.

in the precipitation of chloropyromorphite. The removal of dissolved $\mathrm{Pb}$ (Figure 5b) and the XRD analysis clearly demonstrated the presence of chloropyromorphite in the solids collected from the suspensions with $\mathrm{P} / \mathrm{Pb}$ ratios of $6 / 5$ and $9 / 5$ at pH 2 after 120 -min reaction (not shown). However, the removal of soluble $\mathrm{PO}_{4}$ from solution resulted in the solution becoming undersaturated with respect to chloropyromorphite. Therefore, the precipitation process stopped when $25-30 \%$ of anglesite- $\mathrm{Pb}$ was converted into chloropyromorphite for $\mathrm{P} / \mathrm{Pb}=6 / 5$ and $9 / 5$ at $\mathrm{pH} 2$ (Figure 5a). At $\mathrm{pH} 4$ or $\mathrm{pH} 5$, the solubility of chloropyromorphite was several orders of magnitude lower than that at $\mathrm{pH} 2$ and $\mathrm{pH} 3$. Thus, the precipitation of chloropyromorphite rapidly removed the dissolved $\mathrm{Pb}$ from the solution and enhanced anglesite dissolution, resulting in a complete dissolution of anglesite and transformation of $\mathrm{Pb}$ from anglesite to chloropyromorphite (Figure 5a), regardless of the $\mathrm{P} / \mathrm{Pb}$ ratio. At pH 4 and $\mathrm{pH} 5$, the dissolution rate of apatite was relatively high and provided adequate soluble phosphate for the precipitation of chloropyromorphite (Figures $I$ and 3 , panels $c$ and d). The combination of the low solubility of chloropyromorphite $\left[-\log K_{\mathrm{sp}}=84.4(26)\right]$ and the high dissolution rate of apatite made it possible for complete anglesite dissolution and transformation to chloropyromorphite at these $\mathrm{pH}$ values. In the suspensions with $\mathrm{pH} 6$ and $\mathrm{pH}$ 7, the dissolution rate of apatite was substantially decreased (see Figure 1) and thë amount of dissolved $\mathrm{PO}_{4}$ was limited. Thus, removal of dissolved $\mathrm{Pb}$ was slow, and the solution was saturated with respect to anglesite as the dissolution rate of anglesite is $\mathrm{pH}$ independent (Figure 2). Therefore, incomplete transformation of $\mathrm{Pb}$ from anglesite to chloropyromorphite was obtained (Figure 5a). As with thelow $\mathrm{pH}$ system, in the high $\mathrm{pH}$ system increasing the amount of added apatite provided higher dissolved $\mathrm{PO}_{4}$ for the reaction, resulting in a higher transformation rate. At $\mathrm{pH} 4-5,95-100 \%$ of the anglesite was converted to chloropyromorphite, it dropped to $20-80 \%$ and $18-60 \%$ at $\mathrm{pH} 6$ and 7 , respectively, depending upon the $\mathrm{P} / \mathrm{Pb}$ ratio. Thus, incomplete transformation of anglesite to chloropyromorphite was attributed to deficiency in soluble $\mathrm{PO}_{4}$ at low $\mathrm{pH}$ and slow dissolution rate at high pH (Figure 5a).

The transformation of $\mathrm{Pb}$ from anglesite to chloropyromorphite was incomplete, except at $\mathrm{pH} 4$ and $\mathrm{pH} 5$, within 120-min under the constant $\mathrm{pH}$ condition (Figure $5 \mathrm{~b}$ ). 
However, in the $\mathrm{pH}$ dynamic system, a complete transformation was obtained within $25 \mathrm{~min}$ due to the rapid dissolution of apatite at initial low $\mathrm{pH}$ and precipitation of chloropyromorphite with increasing $\mathrm{pH}$ (Figure 7). Consequently, the soluble $\mathrm{Pb}$ concentration, an important index of bioavailability of ingested $\mathrm{Pb}$, is determined by the solubility of chloropyromorphite [- $\log K_{\text {sp }}=84.4$ (26)] at all $\mathrm{pH}$ levels in the $\mathrm{pH}$ dynamic system (Figures $5 \mathrm{~b}$ and 7 ), whereas in a static pH system, it is determined by the solubility of anglesite at $\mathrm{pH} 2, \mathrm{pH} 3, \mathrm{pH} 6$ and $\mathrm{pH} 7$ (Figure 5b).

The primary concern of immobilization of soil $\mathrm{Pb}$ is reduction in bioavailability of soil $\mathrm{Pb}$ that may be ingested by a small child. The results from the $\mathrm{pH}$-dymamic study illustrated that the transformation of biologically reactive $\mathrm{Pb}$ such as anglesite into chloropyromorphite can be completed within the time scale of the stomach emptying in the GI tract. The significance is that if the transformation of $\mathrm{Pb}$ from the labile soil $\mathrm{Pb}$ forms such as anglesite to chloropyromorphite is not completed prior to ingestion of the soil, the transformation is potentially completed in the GI tract and the bioavailability of soil $\mathrm{Pb}$ will be controlled by chloropyromorphite if there is stoichiometrically adequate amount of phosphate in the digestive system.

In a dynamic soil system, chemical properties including $\mathrm{pH}$ are subject to continuous change, as a result of seasonal changes in hydrology and temperature. Furthermore, changes in local environment such as between the rhizosphere and the bulk soil alter soil $\mathrm{pH}$. These changes certainly affect the transformation rate of $\mathrm{Pb}$ from soil- $\mathrm{Pb}$ into lead phosphate minerals in phosphate-amended soil. Thus, prediction of the rate of transformation from experimental results conducted in a static fashion, i.e., fixed experimental conditions that have generally been adapted, will be in error.

\section{Acknowledgments}

The authors gratefully thank Drs. K. Brackett, P. Clark, and M. Schock for their assistance in SEM and XRD analysis. This research was supported in part by an appointment to the Postgraduate Research Participation Program at the National Risk Management Laboratory administrated by the OakRidge Institute for Science and Education through an interagency agreement between the U.S. Department of Energy and the U.S. Environmental Protection Agency. Although the research in this paper has been undertaken by the U.S. Environmental Protection Agency, it does not necessarily reflect the views of the Agency. Mention of trade names or commercial products does not constitute endorsement or recommendation for use.

\section{Literature Cited}

(1) Freeman, G. B.; Johnson, J. D.; Liao, S. C.; Feder, P. I.; Killinger, J. M.; Chaney, R. L; Bergstrom, P. D. Chem. Speciation Bioavailability 1991, 3, 121-128.

(2) Ruby, M. V.; Davis, A.; Kempton, J. H.; Dnjer, J. W.; Bergstrom, P. Environ. Sci. Technol. 1992, 26, 1242-1248.

(3) Davis, A.; Ruby. M.V.; Goad, P.; Eberle, S.; Chn'ssoulis, S. Environ. Sci. Technol. 1997, 31, 37-44.

(4) Berti, W. R.; Cunningham, S. D. Environ. Sci. Technol. 1997, 31 , 1359-1364.

(5) Laperche, V.; Traina, S. J.; Gaddäam, P.; Logan, T. J. Enuiron. Sci. Technol. 1996, 30, 3321-3326.

(6) Ma, Q. Y.: Traina, S. J.; Logan, T. J.; Ryan, J. A. Enwiron. Sci. Technol. 1993, 27, 1803-1810.

(7) Ma, Q. Y.; Traina, S. J.; Logan, T. J.; Ryan, J. A. Environ. Sci. Technol. 1994, 28, 408-418.

(8) Ma, Q. Y.; Traina, S. J.; Logan, I. J.; Rỵan, J. A. Enuiron. Sci. Technol 1994, 28, 1219-1228.

(9) Ma, Q. Y.; Logan, T. J.; Traina, S. J. Environ. Sci. Tecimol. 1995. 29, 1118- 1126.

(10) Ma, L. Q. J. Environ. Qual. 1996, 25, 1420-1429.

(11) Zhang, P.; Ryan, J.A.; Bryndzia, L. T. Environ. Sci. Teclmol. 1997. $31,2673-2678$.

(12) Nriagu, J. O. Inorg. Chem. 1972, 11, 2499-2503.

(13) Logan, T. J.; Traina, S. J. In Metals in Groundwater, Allen, H. E. Perdue, E. M., Brown, D. S., Eds.; Lewis Publishers: Ann Arbor, MI, 1993; pp 309-347.

(14) Zhang, P.-C.; Ryan, J.A. Soil Science Society of America Annual Meeting, St. Louis, MO, 1995; ASA SSSA; 41.

(15) Ruby, M. V.; Schoof, R.; Eberle, S.; Sellstone, C. M. Environ. Sci. Technol. 1996, 30, 422-430.

(16) Blowes, D.W.; Reardou, E J.; Jambor, J.L; Cherry. J.A. Geochim. Cosmochim. Acta 1991, 55, 965.

(17) Jeffcoat, R. A. Research Triagle Institute for National Institute of Environmental Health Sciences: Research Triagle Park, . $\mathrm{CC}$. 1991.

(18) Hsieh, Y. H.; Huang, C. P. J. Colloid Interface Sci. 1989, 131. $537-549$.

(19) Zhang. P.-C.; Ryan. J. A. Environ. Sci. Technol. In review.

(20) Nriagu, J. O.; Moore, P. B. Phosphate Minerals, Springer-Verlag: New York, 1983.

(21) Lindsay, W. L Chemical Equilibria in Soils, Wiley \& Sons: New . York, 1979.

(22) Nriagu, J. O. Geochim. Cosmochim. Acta 1974, 38, 887-898.

(23) Xu, Y.: Schwartz. F. W. J. Contam. Hydrol. 1994, 15, 187-206.

(24) Wolery, T. J. Lawrence Livemore National Laboratory, Livemore. CA. 1992.

(25) Chen, X; Wright, J. V.; Coñca, J. L.; Peurrung, L M. Enwiron. Sci. Technol. 1997, 31, 624-631.

(26) Dragun. J. The Soil Chemistry of Hazardous Materials, Hazardous Materials Control Research Institute: Silver Springs, MD. 1988.

Received for review March 10, 1998. Revised manuscript received July 6, 1998. Accepted July 27,.1998.

ES980232M
Sandia is a multiprogram laboratory operated by Sandia Corporation, a Lockheed Martin Company, for the United States Department of Energy under contract DE-AC04-94AL85000. 
ES\&T BRIEF FOR MSC: es980232m ISSUE: 021

Formation of Pyromorphite in Anglesite-Hydroxyapatite Suspensions under Varying pH Conditions Pengchu Zhang*

James A. Ryan

In a dynamic $\mathrm{pH}$ system (e.g., $\mathrm{GI}$ tract), soluble $\mathrm{Pb}$ was controlled by chloropyromorphite as anglesite-Pb was completely transformed into chloropyromorphite within $30 \mathrm{~min}$. 
Zhang, ${ }^{\circ}$.

Ryan, J. A. 